\title{
Lingkungan sebagai Media Pembelajaran dan Pengaruhnya terhadap Kompetensi Penyuluh Pertanian
}

\author{
Oos M. Anwas \\ anwasipb@yahoo.co.id, Pustekkom Kemdiknas
}

\begin{abstract}
Abstrak:Penelitian ini bertujuan untuk menganalisis intensitas pemanfaatan lingkungan sebagai media pembelajaran dan pengaruhnya terhadap kompetensi penyuluh pertanian. Penelitian menggunakan metode survai terhadap penyuluh pertanian PNS di kabupaten Karawang dan kabupaten Garut Provinsi Jawa Barat. Sampel diambil secara random sebanyak 170 orang. Hasil analisis deskriptif diketahui secara umum pemanfaatan media lingkungan sebagai media pembelajaran adalah rendah. Rendahnya pemanfaatan ini terutama terjadi dalam dimensi intensitas mengamati lingkungan alam dan lingkungan usaha pertanian, sedangkan pendalaman inovasi mandiri dalam kategori sedang. Hasil analisis regresi diketahui bahwa pemanfaatan media lingkungan yang berpengaruh signifikan terhadap kompetensi penyuluh adalah intensitas pendalaman inovasi mandiri. Oleh karena itu perlu upaya "Gerakan Belajar dengan Lingkungan" melalui langkah-langkah nyata dalam mendorong penyuluh pertanian untuk belajar dengan lingkungan di tempat tugasnya. Perlu dilakukan penelitian lebih lanjut tentang pengaruh pemanfaatan media lingkungan terhadap peningkatan kompetensi pada profesi lain, seperti guru, dosen, dan profesi lainnya.
\end{abstract}

Kata kunci: media pembelajaran, kompetensi, dan penyuluh pertanian

\begin{abstract}
This study aimed to analyze the intensity of utilization of the environment as a medium of learning and its influence on the competency of agricultural extension agents. This study uses a survey of PNS, agricultural extension in the districts of Karawang and Garut district of West Java Province. Samples randomly taken as much as 170 people. Results Descriptive analysis is generally known to use the media environment as a medium of learning is low. The low utilization is particularly true in the dimension of the natural environment and observing the intensity of agricultural business environment, while the deepening of independent innovation in the medium category. Regression analysis found that use of the media environment that significantly influence the intensity of the deepening of the competency of agricultural extension agents are independent innovation. Therefore it is necessary to attempt to "Learning with the Environment Movement" through concrete steps in boosting the agricultural extension agents to study the environment at the place of duty. Need to conduct further research on the influence of environmental media utilization of improved competence of other professions such as teacher, lecture, etc.
\end{abstract}

Key words: medium of learning, competency, and agricultural extension agents

\section{Pendahuluan}

Perkembangan ilmu pengetahuan dan teknologi serta tuntutan perubahan zaman, menuntut setiap individu untuk menyesuaikan dengan perubahan tersebut. Begitu pula dalam profesi apapun seperti peneliti, dosen, guru, dokter, penyuluh, dan profesi lainnya sangat perlu meningkatkan kemampuan atau kompetensinya sesuai dengan tuntutan perubahan zaman.

Peningkatan kemampuan hanya dapat dilakukan melalui proses belajar. Belajar dalam hal ini tidak hanya terbatas pada pendidikan formal atau pelatihan melainkan juga dapat dilakukan dalam pendidikan formal, nonformal, dan informal. Belajar juga dapat dilakukan melalui berbagai media pembelajaran baik yang didesain secara khusus (by desain) untuk pembelajaran atau media yang tidak didesain tetapi dapat dimanfaatkan untuk pembelajaran (by utilization). Salah satu media yang tidak didesain khusus tetapi dapat dimanfaatkan untuk pembelajaran (by utilization) tersebut adalah media lingkungan. 
Lingkungan yang ada di sekitar kita, tempat tinggal atau tempat bertugas merupakan media pembelajaran yang murah, mudah, dan jumlahnya hampir tak terbatas. Lingkungan ini mulai dari lingkungan alam, lingkungan sosial budaya, lingkungan inovasi, dan lingkungan lainnya.

Profesi seperti penyuluh pertanian yang tugas utamanya adalah di lapangan dalam memberdayakan petani, lingkungan tidak hanya sebagai tempat bekerja. Lingkungan tempat mereka bertugas merupakan sumber inspirasi dan tempat untuk belajar. Bagi penyuluh, belajar dengan lingkungan tidak hanya paham akan kebutuhan dan permasalahan petani, akan tetapi akan mampu menselaraskan kebutuhan dan tuntutan masyarakat dengan perkembangan inovasi dan teknologi baru. Ini dapat diasumsikan bahwa penyuluh yang belajar dengan lingkungan, kompetensinya dapat meningkat. Oleh karena itu, menarik untuk dilakukan penelitian tentang bagaimana intensitas pemanfaatan media lingkungan, dan media lingkungan apa yang memiliki pengaruh signifikan terhadap peningkatan kompetensi penyuluh pertanian.

Rumusan masalah dalam penelitian ini adalah bagaimana intensitas pemanfaatan lingkungan sebagai media pembelajaran dalam peningkatan kompetensi penyuluh pertanian dan apakah intensitas pemanfaatan lingkungan sebagai media pembelajaran dapat meningkatkan kompetensi penyuluh pertanian. Berdasarkan permasalahan tersebut, tujuan penelitian ini adalah: 1) menganalisis intensitas pemanfaatan lingkungan sebagai media pembelajaran dalam peningkatan kompetensi penyuluh dan 2) menganalisis pengaruh intensitas pemanfaatan lingkungan sebagai media pembelajaran dalam peningkatan kompetensi penyuluh pertanian.

\section{Kajian Pustaka}

Kata media berasal dari bahasa Latin yang merupakan bentuk jamak dari kata medium, secara harfiah diartikan sebagai perantara atau pengantar. Media juga sering diartikan sebagai sarana komunikasi untuk mengantarkan pesan. Dalam pembelajaran, media digunakan untuk membantu pemahaman peserta didik dalam mencapai tujuan pembelajaran. Gagne (Sadiman, dkk, 1986) menyatakan bahwa media pembe- lajaran adalah berbagai jenis komponen dalam lingkungan siswa yang dapat merangsangnya untuk belajar. Pendapat Gagne ini senada dengan penjelasan AECT (1984) bahwa media pembelajaran adalah segala bentuk dan saluran yang digunakan orang untuk menyalurkan pesan/ informasi.

Secara umum media pembelajaran dapat dibagi dua yaitu media yang dirancang secara khusus (by design) untuk pembelajaran dan media yang tidak dirancang untuk belajar tetapi dapat dimanfaatkan untuk proses pembelajaran (by utilization). Salah satu bentuk media belajar yang tidak dirancang tersebut adalah lingkungan (Anderson, 1994), (AECT, 1984).

Lingkungan adalah segala sesuatu yang sifatnya eksternal terhadap diri individu, karena lingkungan merupakan sumber informasi yang diperoleh melalui pancaindera yang kemudian diterima oleh otak (Djaafar, 2001). Lingkungan menyediakan berbagai hal yang dapat menjadi bahan pembelajaran. Jumlah sumber belajar yang tersedia di lingkungan ini tidaklah terbatas. Hal ini sangat bergantung pada sejauh mana yang bersangkutan bisa memanfaatkannya secara efektif.

Lingkungan diasumsikan memiliki keefektifan belajar dalam meningkatkan kemampuan. Dale (Sadiman, dkk, 1986) mengklasifikasikan pengalaman belajar menurut tingkat yang paling kongkrit ke yang paling asbtrak, yang dikenal dengan nama Kerucut Pengalaman (core of experience). Menurut Dale, proses belajar yang paling rendah diperoleh melalui pesan verbal, sedangkan yang paling tinggi adalah melalui pengalaman langsung. Ini berarti proses belajar yang efektif bagi penyuluh adalah pengalamanpengalaman yang langsung ditemukan, dirasakan, dan dilakukan di lingkungan tempat tugasnya.

Secara umum lingkungan dapat dikelompokkan menjadi tiga, yaitu lingkungan alam atau lingkungan fisik, lingkungan sosial, dan lingkungan budaya. Lingkungan alam atau lingkungan fisik adalah segala sesuatu yang sifatnya alamiah, seperti sumber daya alam (air, hutan, tanah, batu-batuan), tumbuh-tumbuhan dan hewan (flora dan fauna), sungai, iklim, suhu, dan sebagainya. Lingkungan sosial terkait dengan kehidupan bermasyarakat. Lingkungan budaya 
adalah lingkungan yang sengaja diciptakan atau dibangun manusia untuk tujuan-tujuan tertentu yang bermanfaat bagi kehidupan manusia.

Bagi profesi penyuluh pertanian, lingkungan tidak hanya sebagai tempat bekerja tetapi juga menjadi media belajar. Lingkungan yang baik untuk peningkatan kompetensi penyuluh adalah lingkungan yang dapat memperkaya pengetahuan, sikap, dan keterampilannya yang terkait dengan pelaksaaan tugasnya sebagai penyuluh. Banyak keuntungan yang diperoleh dengan memanfaatkan lingkungan sebagai media belajar. Melalui media lingkungan, penyuluh dapat berinteraksi secara langsung dengan lingkungan tempat tugasnya, lebih mengenal karakteristik, potensi wilayah, termasuk permasalahan yang dihadapi daerah tersebut. Pemahaman lebih mendalam dengan lingkungan memungkinkan penyuluh untuk lebih mudah beriteraksi dengan petani (klien), sehingga memudahkan dalam pencapaian tujuan penyuluhan.

Keuntungan lain dalam pemanfaatan lingkungan sebagai media belajar adalah belajar dapat dilakukan kapan saja setiap ada kesempatan. Begitu pula belajar tidak memerlukan peralatan khusus, seperti: buku, ruangan khusus, aliran listrik, dan sarana lainnya. Dalam belajar seringkali biaya menjadi kendala. Dengan memanfaatkan lingkungan sebagai media belajar berarti dapat menghemat biaya pendidikan. Dengan pemahaman lingkungan, berarti penyuluh dapat menselaraskan perkembangan informasi dan inovasi dengan tuntutan kebutuhan petani di lapangan.

Dalam penelitian ini, lingkungan sebagai media pembelajaran diartikan sebagai suatu kondisi di sekitar tempat tugas penyuluh yang dapat digunakan untuk meningkatkan kemampuannya yang terkait dengan pelaksaaan tugasnya sebagai penyuluh. Lingkungan yang dimaksudkan adalah lingkungan alam, lingkungan usaha pertanian, dan lingkungan pendalaman inovasi mandiri.

Lingkungan alam adalah suatu kondisi alam dan perubahannya yang terjadi di lingkungan penyuluhan. Lingkungan yang dimaksudkan adalah air, tanah, potensi lahan, dan iklim di sekitar tempat tugasnya. Usaha pertanian adalah suatu industri biologis yang memanfaatkan materi dan proses hayati untuk memperoleh laba yang layak bagi pelakunya yang dikemas dalam berbagai subsistem mulai dari subsistem praproduksi, produksi, panen dan pascapanen serta distribusi dan pemasaran (Badan Litbang Pertanian, 1999). Pengertian usaha pertanian ini sama dengan pengertian Agribisnis. Lingkungan pendalaman inovasi mandiri adalah aktivitas penyuluh dalam mendalami teknologi atau caracara baru dalam usaha pertanian yang tepat untuk diterapkan di tempat tugasnya secara mandiri.

Konsep kompetensi mengacu pada pemikiran Boyatzis (1984), Spencer and Spencer (1993), Sumardjo, (2008), yang dapat disarikan bahwa kompetensi adalah kemampuan yang dilandasi oleh pengetahuan, keterampilan, dan didukung oleh sikapnya yang dituntut dalam melaksanakan tugas pekerjaannya. Ini berarti kompetensi penyuluh pertanian adalah kemampuan yang dilandasi oleh pengetahuan, keterampilan, dan didukung oleh sikap yang dituntut dalam melaksanakan tugasnya dalam memberdayakan petani. Kompetensi penyuluh dalam upaya memberdayakan petani, dikelompokkan ke dalam tujuh jenis kompetensi, yaitu: 1) Kompetensi pemahaman potensi wilayah, 2) Kompetensi komunikasi inovasi, 3) Kompetensi pengelolaan pembelajaran, 4) Kompetensi pengelolaan pembaharuan, 5) Kompetensi pengelolaan pelatihan, 6) Kompetensi pengembangan kewirausahaan, dan 7) Kompetensi pemandu sistem jaringan (Anwas, 2009). Penyuluh yang memiliki kompetensi baik adalah penyuluh yang dapat memberdayakan petani atau peningkatkan partisipasi kepada petani seluas-luasnya untuk menjadi subjek dalam usaha pertaniannya.

\section{Metodologi Penelitian}

Penelitian ini menggunakan metode survai, yaitu cross sectional survey di mana pengumpulan data penelitian dilakukan pada saat yang bersamaan antara variabel $X$ dengan $Y$. Variabel yang diteliti adalah intensitas pemanfaatan lingkungan sebagai media pembelajaran, yaitu intensitas mengamati lingkungan alam (X1), lingkungan usaha pertanian (X2), dan lingkungan inovasi mandiri (X3). Variabel indenpenden adalah kompetensi penyuluh pertanian $(\mathrm{Y})$. Populasi 
dalam penelitian ini adalah penyuluh pertanian Pegawai Negeri Sipil yang bertugas di daerah pertanian padi kabupaten Karawang dan penyuluh yang bertugas di daerah pertanian sayuran di kabupaten Garut Provinsi Jawa Barat. Sampel diambil secara random menggunakan teknik random sampling dengan rumus Slovin (Sevilla $d k k ., 1993$ ) pada kelonggaran sebesar 7 persen. Hasil perhitungan dengan rumus tersebut diperoleh jumlah sampel sebanyak 170 penyuluh.

Instrumen penelitian sebelumnya telah teruji melalui uji coba terhadap 30 penyuluh pertanian di kabupaten Bogor, Jawa Barat. Hasil uji coba ini selanjutnya dilakukan uji validitas dengan cara skor tiap item dikorelasikan (korelasi Product moment) antara skor tes dengan skor kriteria. Uji reliabilitas menggunakan teknik Alpha Cronbach. Melalui hasil uji tersebut, instrumen penelitian terbukti valid dan reliabel.

Pengumpulan data dilakukan pada bulan April 2009. Data yang dikumpulkan menggunakan kuesioner dan wawancara mendalam (indepht interview). Hasil wawancara ini menjadi data kualitatif yang dapat melengkapi dan menjelaskan hasil uji statistik. Pengolahan data menggunakan analisis statistik deskriptif dan analisis regresi berganda, dengan bantuan aplikasi SPSS versi 14 .

\section{Hasil dan Pembahasan}

Hasil analisis deskriptif diketahui bahwa secara umum intensitas pemanfaatan media lingkungan yaitu intensitas pengamatan terhadap lingkungan alam, intensitas pengamatan terhadap lingkungan usaha pertanian, dan intensitas pendalaman inovasi mandiri dalam kategori rendah (Tabel 1).
Hasil ini menunjukkan bahwa penyuluh secara umum masih belum terbiasa memanfaatkan media lingkungan sebagai media belajar dalam meningkatkan kemampuanya. Padahal media tersebut banyak tersedia di lingkungan tempat mereka bertugas. Mereka dapat memanfaatkannya tanpa harus mengeluarkan pengorbanan materil, seperti belajar dalam pendidikan formal. Menurut AECT (1984), proses belajar tidak hanya dengan media yang direncanakan secara khusus, tetapi berbagai hal yang ada di sekitar kita (lingkungan) dapat dimanfaatkan (by utilization) untuk kegiatan belajar dalam meningkatkan kemampuan.

Secara rinci intensitas pengamatan lingkungan alam yang terkait dengan usaha tani menunjukkan skor sangat rendah dengan rataan skor hanya 16 (Tabel 1 ). Kondisi ini dapat ditarfsirkan bahwa intensitas pengamatan penyuluh terhadap lingkungan alam dalam aspek: mengamati ketersediaan air, mengamati kesuburan tanah, mengamati potensi lahan, dan intensitas mengamati perubahan iklim di daerah padi dan sayuran sama-sama sangat rendah. Hasil ini juga dapat ditafsirkan bahwa penyuluh kurang memperhatikan perubahan alam yang terjadi di tempat tugasnya. Padahal dalam lingkungan pertanian perubahan alam sangat menentukan terhadap komoditas dan perlakuan tanaman. Misalnya, hama tanaman setiap musim berbeda dan juga penanganannya berbeda pula. Di sisi lain hasil pendalaman dengan penyuluh, menjelaskan bahwa petani setiap hari melakukan proses belajar dengan alam dan perubahannya.

Intensitas pengamatan lingkungan usaha pertanian menunjukkan skor sangat rendah yaitu

Tabel 1. Sebaran Persentase dan Rataan Skor Pemanfaatan Media Lingkungan

\begin{tabular}{|c|c|c|c|c|c|}
\hline \multirow[b]{2}{*}{ Variabel } & \multicolumn{4}{|c|}{ Kategori \% } & \multirow[b]{2}{*}{$\begin{array}{l}\text { Rataan } \\
\text { Skor }\end{array}$} \\
\hline & $\begin{array}{l}\text { Sangat } \\
\text { Rendah }\end{array}$ & Rendah & Sedang & Tinggi & \\
\hline $\begin{array}{l}\text { Intensitas Pemanfaatan } \\
\text { Lingkungan alam }\end{array}$ & 82 & 15 & 2 & 1 & 16 \\
\hline $\begin{array}{l}\text { Intensitas Pemanfaatan } \\
\text { Lingkungan Usaha Pertanian }\end{array}$ & 66 & 27 & 8 & 0 & 21 \\
\hline $\begin{array}{l}\text { Intensitas Pendalaman Inovasi } \\
\text { Mandiri }\end{array}$ & 1 & 51 & 41 & 7 & 51 \\
\hline
\end{tabular}

Keterangan: $0-25=$ Sangat rendah, $26-50=$ Rendah, $51-75=$ Sedang, $76-$ $100=$ Tinggi 
rataan skor 16 (Tabel 1 ). Kondisi ini dapat ditarfsirkan bahwa intensitas pengamatan lingkungan usaha pertanian dalam aspek: pengamatan dalam penyediaan benih, pengolahan lahan, pemupukan, penanaman, membasmi hama, memanen hasil, pasca panen, dan intensitas pengamatan memasarkan hasil panen di daerah padi dan sayuran sama-sama sangat rendah. Padahal lingkungan usaha pertanian terutama di daerah sayuran dinamikanya cukup tinggi. Perubahan dalam lingkungan usaha pertanian berdampak pada berbagai aspek yang terkait dengan pertanian mulai dari praproduksi, produksi, dan pascaproduksi (pemasaran) hasil pertanian. Kondisi ini termasuk dengan segala peru-bahannya penting dipahami penyuluh sebagai modal mereka untuk memberdayakan petani.

Hasil pendalaman dengan beberapa penyuluh di lokasi penelitian ditemukan bahwa rendahnya pengamatan terhadap lingkungan alam dan usaha pertanian disebabkan kemajuan teknologi informasi dan komunikasi, petani seringkali mendapatkan informasi dari berbagai saluran. Akibatnya, dalam banyak hal petani lebih dulu paham terhadap inovasi atau teknologi baru. Jika ada masalah dalam menerapkan hal baru itu, petani bertanya kepada penyuluh. Ini yang menjadi tantangan berat bagi penyuluh untuk menjawab tuntutan masyarakat, sehingga mereka menjadi malas melakukan kunjungan lapangan baik ke lahan pertanian ataupun kunjungan kepada para petani.

Pemanfaatan media lingkungan dalam dimensi intensitas pendalaman inovasi mandiri menunjukkan kategori sedang yaitu dengan rataan skor 51 . Ini berarti intensitas pendalaman inovasi mandiri yang diukur dalam aspek intensitas mencari referensi inovasi/teknologi baru melalui berbagai sumber belajar yang tersedia di sekitar lingkungan tempat tugasnya, intensitas melakukan uji coba inovasi/teknologi baru, intensitas keterlibatan petani dalam uji coba, serta intensitas menganalisis petani yang sukses dan gagal dalam menerapkan inovasi dalam kategori tidak tinggi. Menurut hasil pendalaman dengan beberapa penyuluh senior, kondisi ini terjadi karena pendalaman inovasi mandiri untuk tanaman sayuran memerlukan lahan khusus dan modal yang relatif besar, sehingga penyuluh di daerah sayuran kesulitan melakukan pendalaman inovasi mandiri. Mereka juga mengakui bahwa penyuluh sangat kurang untuk melakukan pembuktian atau uji coba inovasi atau teknologi baru di lapangan. Penyuluh kurang sarana dan biaya untuk melakukannya, karena biaya uji coba untuk sayuran sangat besar. Ini adalah pekerjaan rumah bagi pemerintah dalam hal ini pemerintah daerah dan lembaga penyuluhan di daerah untuk dapat meningkatkan kegiatan pendalaman inovasi mandiri sebagai salah satu bentuk kegiatan belajar bagi penyuluh di tempat tugasnya.

Proses pembuktian atau uji coba inovasi secara mandiri tidak berarti hanya dilakukan oleh penyuluh sendiri, akan tetapi perlu melibatkan petani. Hal ini perlu kreativitas penyuluh dan juga menanamkan kepercayaan kepada petani agar mau secara bersama-sama melakukan uji coba atau pembuktian terhadap inovasi. Hasil pendalaman dengan beberapa penyuluh senior di daerah padi menjelaskan pengalamannya dalam melakukan uji coba bersama petani. Petani malahan senang lahannya dijadikan contoh percobaan. Ini memang pentingnya penyuluh menanamkan kepercayaan dan komunikasi yang harmonis dengan petani.

Untuk mengetahui media lingkungan yang berpengaruh langsung dan nyata terhadap kompetensi penyuluh dilakukan uji regresi. Hasil uji regresi diketahui intensitas pengamatan lingkungan alam $(\alpha=0,925)$ dan pengamatan lingkungan usaha pertanian $(\alpha=0,893)$ adalah tidak signifikan yang dibuktikan dengan nilai $\alpha>$ 0,05 (Tabel 2). Jika mengacu pada Tabel 1, bahwa intensitas pengamatan lingkungan alam dan pengamatan lingkungan usaha pertanian yang dilakukan oleh penyuluh frekuensinya sangat rendah, masing-masing hanya 16 dan 21. Rendahnya intensitas ini diduga menjadi penyebab tidak ada berpengaruh antara intensitas pengamatan lingkungan alam dan pengamatan lingkungan usaha pertanian terhadap peningkatan kompetensi penyuluh.

Pemanfaatan media lingkungan dalam dimensi pendalaman inovasi mandiri diketahui berpengaruh nyata terhadap kompetensi penyuluh yang dibuktikan dengan nilai $\alpha=0,000$ dan koefisien regresi 0,361 (Tabel 2). 
Tabel 2. Hasil Uji Regresi Pengaruh Lingkungan sebagai Media Pembelajaran terhadap Kompetensi Penyuluh Pertanian

\begin{tabular}{|l|c|c|}
\hline Lingkungan sebagai media pembelajaran & $\begin{array}{c}\text { Koefisien yang telah } \\
\text { distandarisasi }\end{array}$ & $\begin{array}{c}\text { Nilai } \\
\text { signifikan }\end{array}$ \\
\hline Intensitas pengamatan lingkungan alam & 0,007 & 0,925 \\
\hline $\begin{array}{l}\text { Intensitas pengamatan lingkungan usaha } \\
\text { pertanian }\end{array}$ & 0,010 & 0,893 \\
\hline \begin{tabular}{l} 
Intensitas pendalaman inovasi mandiri \\
\hline
\end{tabular} & 0,361 & 0,000 \\
\hline
\end{tabular}

Diketahuinya intensitas pendalaman inovasi mandiri berpengaruh nyata terhadap kompetensi bermakna bahwa intensitas penyuluh mendalami secara mandiri tentang inovasi atau teknologi baru dalam usaha pertanian di tempat tugasnya sangat penting. Kegiatan ini terdiri dari: pendalaman terhadap inovasi atau teknologi baru yang berkaitan dengan usaha pertanian melalui berbagai sumber belajar yang tersedia di sekitar lingkungan tempat tugasnya, melakukan uji coba inovasi di lapangan dengan melibatkan partisipasi petani, belajar terhadap petani yang berhasil dalam mengadopsi inovasi termasuk menganalisis petani yang gagal.

Jika mengacu pada kerucut pengalaman (core of experience) dari Dale (Sadiman, dkk, 1984), pendalaman inovasi mandiri merupakan proses belajar dalam bentuk uji coba dan memperoleh pangalaman yang langsung di lapangan. Pengalaman belajar yang diperoleh secara langsung menurut Dale merupakan proses belajar yang paling kongrit sehingga hasil penelitian ini membuktikan bahwa pendalaman inovasi mandiri berpengaruh nyata dan positif terhadap kompetensi penyuluh.

Hasil pendalaman dengan responden di lapangan, diketahui bahwa seorang penyuluh yang diakui kredibel di masyarakat karena ia sering melakukan uji coba secara mandiri. Kegiatan uji coba ini dilakukan dengan modal pribadi karena lembaga penyuluhan tidak mampu menyediakan baik lahan maupun biayanya. Hal ini bisa dilakukan secara mandiri karena yang bersangkutan memiliki lahan pertanian yang cukup dan memiliki usaha sayuran. Hasil belajar penyuluh melalui proses uji coba lapangan ini ternyata mampu meningkatkan kemampuannya dalam bidang tanaman sayuran, sehingga menjadi contoh bagi petani di tempat tugasnya.

Hasil pendalaman lainnya dengan responden diketahui bahwa penyuluh melakukan uji coba tidak hanya dilakukan di lahan percobaan, tetapi juga dilakukan pada lahan petani. Upaya ini bekerja sama dengan petani teladan, misalnya ketua kelompok tani. Hasil uji cobanya kemudian disebarluaskan kepada petani sekitarnya. Dalam hal ini petani percaya karena melihat langsung proses dan hasil usaha pertanian yang dilakukan oleh penyuluh bersama-sama petani tersebut. Model kegiatan uji coba yang bekerja sama dengan petani ini hanya dapat dilakukan oleh sebagian kecil penyuluh saja. Penyebabnya, tidak semua penyuluh bisa meyakinkan petani untuk melakukan ujiicoba bersama tersebut. Apalagi uji coba di daerah sayuran menurut pengakuan beberapa penyuluh senior di Garut sulit dilakukan di lahan petani, karena memerlukan biaya relatif besar dan kemungkinan resiko gagal relatif besar. Oleh karena itu beberapa penyuluh senior di Garut mengusulkan bahwa untuk meningkatkan kompetensi penyuluh, kegiatan uji coba sangat penting dan perlu difasilitasi oleh pemerintah.

Pendalaman inovasi mandiri merupakan faktor yang sangat penting sebagai media lingkungan dalam meningkatkan kompetensi penyuluh. Hal ini dapat dipahami bahwa pendalaman inovasi mandiri merupakan upaya penyuluh dalam memahami dan menselaraskan inovasi dan teknologi yang berkembang sesuai dengan kebutuhan petani. Ini adalah prinsip penyuluhan harus didasarkan pada kebutuhan dan permasalahan petani. Salah satu sifat dasar dari suatu inovasi adalah harus dapat diuji cobakan oleh pengguna (Rogers dan Shoemaker, 1987) 
dalam hal ini oleh penyuluh bersama dengan petani. Petani lebih percaya pada inovasi dan teknologi baru yang mereka bisa langsung melihatnya, diantaranya melalui proses uji coba.

Pendalaman inovasi mandiri juga dapat meningkatkan partisipasi petani dalam proses uji coba. Partisipasi klien dapat dilakukan dengan memfasilitasi kesempatan (Slamet, 2003) dan mengetahui tujuan, langkah, prosesnya, tahapan lainnya dari inovasi tersebut Asngari (2001). Mengacu pada Kerucut Pengalaman Dale (Sadiman, 1986) bahwa pendalaman inovasi mandiri merupakan pengalaman belajar yang langsung dilakukan oleh penyuluh sehingga menjadi pengalaman kongkrit dan efektif dalam pencapaian tujuan pembelajaran.

Pemanfaatan media lingkungan merupakan proses belajar mandiri. Secara mandiri baik sendiri atau bekerja sama dengan petani dan pihak lainnya, penyuluh mendalami inovasi atau teknologi baru tentang usaha pertanian disesuaikan dengan kebutuhan, permasalahan, dan potensi klien/petani yang benar-benar terjadi di lapangan. Ini berarti kompetensi penyuluh akan meningkat sesuai dengan tuntutan kebutuhan nyata petani di lapangan, karena penyuluh tersebut memanfaatkan lingkungan sebagai media pembelajaran.

\section{Simpulan dan Saran Simpulan}

Secara umum pemanfaatan lingkungan sebagai media pembelajaran dalam kategori rendah. Rendahnya pemanfaatan media lingkungan ini terutama terjadi dalam dimensi intensitas mengamati lingkungan alam dan lingkungan usaha pertanian, sedangkan pendalaman inovasi mandiri dalam kategori sedang.

Pemanfaatan media lingkungan dalam dimensi pendalaman inovasi mandiri memiliki pengaruh yang signifikan dan positif terhadap peningkatan kompetensi penyuluh pertanian. Adapun indikator pemanfaatan media lingkungan dalam dimensi pendalaman inovasi mandiri adalah pendalaman terhadap inovasi atau teknologi baru yang berkaitan dengan usaha pertanian, melakukan uji coba inovasi sesuai dengan kondisi di lapangan dan melibatkan partisipasi petani, belajar terhadap petani yang berhasil dalam menerapkan inovasi, serta menganalisis petani yang gagal dalam menerapkan inovasi. Dengan kata lain, pendalaman inovasi mandiri merupakan proses belajar mandiri yang dilakukan penyuluh pertanian melalui pemanfaatan lingkungan di tempat tugasnya, sehingga dapat menguasai inovasi atau teknologi baru tentang usaha pertanian yang disesuaikan dengan situasi dan kondisi lapangan.

\section{Saran}

Hasil penelitian ini menunjukkan bahwa pemanfaatan media lingkungan terutama dalam dimensi pendalaman inovasi mandiri memiliki pengaruh signifikan terhadap kompetensi penyuluh, namun pemanfaatan media ini oleh penyuluh masih belum tinggi. Oleh karena itu perlu dilakukan langkah-langkah untuk meningkatkan pemanfaatan media lingkungan khususnya pendalaman inovasi mandiri yaitu mendorong penyuluh untuk melakukan uji coba inovasi dan hasil-hasil penelitian dengan cara: memfasilitasi penyediaan lahan, anggaran, bibit/benih, dan hasil-hasil teknologi lainnya. Upaya ini dapat dilakukan dengan melalui: 1) penyediaan anggaran pemerintah daerah, 2) kerja sama dengan petani, atau 3) kerja sama kemitraan dengan pihak swasta. Pelaksanaan uji coba ini dilakukan antara penyuluh dan partisipasi petani. Inovasi atau teknologi baru yang diuji cobakan didasarkan pada kebutuhan dan permasalahan yang dihadapi petani, menguntungkan, mampu diuji cobakan, mudah dipahami, dan yang lebih penting hasilnya dapat dilihat/dinilai petani. Pengalaman petani di lapangan dalam mempraktekkan inovasi/teknologi baru bisa menjadi bahan untuk dikaji dan diuji coba bersama.

Upaya lain dalam meningkatkan pendalaman inovasi mandiri dapat dilakukan dengan cara: 1) memfasilitasi penyediaan bahan referensi di tempat tugasnya untuk mendalami inovasi, seperti: buku, majalah, dan akses media massa elektronik yang relevan, misalnya majalah, koran, siaran televisi, radio, internat, serta sumber belajar lainnya; 2) Meningkatkan partisipasi petani dan pihak terkait lainnya dalam melakukan uji coba inovasi. Uji coba ini tidak hanya menekankan pada hasil melainkan juga prosesnya sehingga bisa 
dilakukan dan dipahami bersama dengan petani dan masyarakat; 3) Memberikan apresiasi kepada penyuluh penyuluh yang berhasil dalam melakukan uji coba inovasi, pemilihan penyuluh berprestasi, pemberian beasiswa atau kenaikan pangkat istimewa bagi penyuluh yang berprestasi, dan bentuk penghargaan lainnya; dan 4) Menumbuhkan kesadaran penyuluh untuk belajar dengan lingkungan sebagai media belajar yang efektif dan murah menjadi sebuah "Gerakan Belajar dengan Lingkungan." Upaya ini dapat dilakukan dengan cara mendorong penyuluh untuk membaca kebutuhan dan potensi lingkungan, belajar terhadap petani yang sukses/ gagal dalam menerapkan inovasi, belajar dengan alam dengan cara mengamati alam dan perubahanya, serta mempelajari kearifan lokal yang dilakukan petani di tempat tugasnya. Semua ini merupakan pengalaman berharga dalam meningkatkan kemampuan penyuluh guna meningkatkan kualitas penyuluhan yang sesuai dengan harapan masyarakat/ klien.

Perlu dilakukan penelitian lebih lanjut tentang pemanfaatan lingkungan sebagai media pembelajaran pada profesi lain seperti: guru, dosen, peneliti, dokter, dan pegawai (staf dan pimpinan) di lingkungan tempat mereka bertugas dalam meningkatkan kompetensinya baik di lembaga pemerintah maupun swasta.

\section{Pustaka Acuan}

AECT. 1984. Definisi Teknologi Pendidikan: Satuan Tugas, Definisi, dan Terminologi AECT. Jakarta: Rajawali.

Anderson, Ronal H., 1994. Selecting and Developing Media for Instruction, Edisi Indonesia, Jakarta: RajaGrafindo Persada.

Anwas, Oos M. 2009. Pemanfaatan Media dalam Pengembangan Kompetensi Penyuluh Pertanian. Disertasi: Program Studi Ilmu Penyuluhan Pembangunan, Departemen Sains Komunikasi dan Pengembangan Masyarakat Pascasarjana IPB Bogor.

Asngari, Pang S. 2001. Peranan Agen Pembaharuan/Penyuluh dalam Usaha Memberdayakan (empowerment) Sumber Daya Manusia Pengelola Agribisnis. Orasi Ilmiah Guru Besar Tetap IImu Sosial Ekonomi IPB. Bogor, 15 September.

Badan Litbang Pertanian. 1999. Panduan Umum Pelaksanaan Penelitian, Pengkajian dan Diseminasi Teknologi Pertanian. Jakarta: Badan Litbang Pertanian. http://pse.litbang.deptan.go.id/ind/ pdffiles/ART03-4c.pdf. (21 Juli 2008)

Boyatzis, RE. 1984. The Competent Manager: A Model for Effective Performance. New York: Jihn Willy \& Sons.

Djaafar, Zahara. 2001. Pendidikan Non Formal dan Peningkatan Kualitas Sumber Daya Manusia Dalam Pembangunan: Padang: Fakultas Ilmu Pendidikan, Universitas Negeri Padang

Rogers, Everett M. dan F. Floyd Shoemaker. 1987. Communication of innovations terjemahan Abdillah Hanafi "Memasyarakatkan Ide-Ide Baru. Surabaya: Usaha Nasional.

Sadiman, Arief S, R. Rahardjo, Anung Haryono, dan Rahardjito. 1986. Media Pendidikan: Pengertian, Pengembangan, dan Pemanfaatanya. Jakarta: Rajawali.

Spencer, M. Lyle dan M. Signe Spencer. 1993. Competence at Work: Models for Superrior Performance, John Wily \& Son, Inc. New York, USA

Sevilla, C. G., J. A. Ochave, T. G. Punsalan, B. P. Regala, dan G. G. Uriarte. 1993. Pengantar Metode Penelitian. Jakarta: Universitas Indonesia Press.

Slamet, Margono. 2003. "Menata Sistem Penyuluhan Pertanian Menuju Pertanian Modern." Dalam Membentuk Pola Perilaku Manusia Pembangunan. Diedit oleh: Adjat Sudrajat dan Ida Yustina. Bogor: IPB Press.

Sumardjo. 2008. "Penyuluhan Pembangunan: Pilar Pendukung Kemajuan dan Kemandirian Masyarakat." Dalam Pemberdayaan Manusia Pembangunan yang Bermartabat. Penyunting: Adjat Sudrajat dan Ida Yustina. Bogor: Sydex Plus. 